\title{
EMPIRICAL PREDICTION OF PHYSIOLOGICAL RESPONSE TO PROLONGED WORK IN ENCAPSULATING PROTECTIVE CLOTHING
}

\author{
P. Bishop, P. Reneau, P. Ray, and M. Wang
}

The University of Alabama, Box 870312, Tuscaloosa, AL 35487-0312, USA

\section{INTRODUCTION}

Workers wearing protective clothing (PC) required to perform physical labor in hazardous environments at temperatures greater than $21^{\circ} \mathrm{C}\left(70^{\circ} \mathrm{F}\right)$ incur a risk of heat-injury, and a reduced work capacity $(1,2,3,4)$. Current prediction methods, although useful in many applications, do not provide sufficient accuracy for individualized prediction. The use of group mean predictions such as the American Conference of Government Industrial Hygienists (ACGIH) Threshold Limit Values (TLVs) puts some personnel at risk, while at the same time other workers are under-utilized (3) and this presents two major disadvantages: 1) Individuals are too much constrained by the very conservative limits needed for protection of almost all workers, such that their individual productivity is substantially reduced, 2) Because productivity is so compromised, and because some managers undoubtedly consider the TLVs to be overly conservative, it can reasonably be presumed that the TLVs are violated frequently. Since there are no alternative resources for managing personnel in this situation, the net result can be increased, rather than decreased risk to workers.

The purpose of this study was to develop a technique for predicting physical work capacity of individuals in these situations, based upon field measurements gathered in a short-term work task performed in protective clothing in a mild ambient environment (i.e. bench stepping in PC at room temperature). This research was built upon recent work done in our laboratory (5) as well as earlier work of Kenny et al. (6), and Shvartz et al. (7).

\section{MATERIALS AND METHODS}

Fifty unacclimatized young fit males performed a $\mathrm{VO}_{2}$ max test, then performed two identical bench stepping tests wearing PC (one-piece Saranex suit with respirator PVC shoe covers and gloves) on a $40 \mathrm{~cm}$ bench at a metronome paced rate of 24 steps $/ \mathrm{min}$ in an environment of WBGT $=18^{\circ} \mathrm{C}$.

Work $\mathrm{VO}_{2}$, rectal (Tre) and mean skin temperatures (mTsk) (8), and qualitative ratings of comfort (modified from 9), and Rating of Perceived Exertion (RPE) (10) were measured during the bench-stepping. 
Subjects then performed the following in counterbalanced order:

1) Continuous work at $177 \mathrm{~W} / \mathrm{m}^{2}\left(300 \mathrm{Kcal} / \mathrm{hr}, \mathrm{VO}_{2}\right.$ of $1 \mathrm{~L} / \mathrm{min}$, at WBGT $=18^{\circ} \mathrm{C}$ (i.e. room temperature), referred to as $18 / 1.0$

2) $30 \mathrm{~min}$ work at $235 \mathrm{WW} / \mathrm{m}^{2}$ ( $400 \mathrm{Kcal} / \mathrm{hr}, \mathrm{VO}_{2}$ of $1.33 \mathrm{~L} / \mathrm{min}$ ) succeeded by 30 $\min$ rest $35 \mathrm{~W} / \mathrm{m}^{2}\left(60 \mathrm{Kcal}\right.$, time weighted avg of $\left.135 \mathrm{~W} / \mathrm{m}^{2}\right)$ all at WBGT $=18^{\circ} \mathrm{C}$ referred to as $18 / 1.3$

3) Same as \#1 in WBGT $=26^{\circ} \mathrm{C}$, referred to as $26 / 1.0$

4) Same as $\# 2$ in WBGT of $26^{\circ} \mathrm{C}$, referred to as $26 / 1.3$.

All rest was performed with the gloves and gas protective mask removed and PC removed to the waist. Resting metabolic rate was assumed to be $35 \mathrm{~W} / \mathrm{m}^{2}$. Work consisted of $15 \mathrm{~min}$ of walking at $1.34 \mathrm{~m} / \mathrm{sec}(3 \mathrm{mph}$ ) followed by $5 \mathrm{~min}$ of arm curls with $14.6 \mathrm{~kg}$ of weight, with this work sequence repeated until the specified time limit.

Subjects were stopped by investigators if: 1) rectal temperature (Tre) exceeded $38^{\circ} \mathrm{C}$, or 2) heart rate (HR) was within 10 beats of measured maximal heart rate, or 3) subject evidenced symptoms of heat injury or extreme fatigue. Subjects were able to stop work at any time. When Tre fell below $37.5^{\circ} \mathrm{C}$, and $\mathrm{HR}$ and subject felt rested, work resumed. Subjects were allowed water ad libitum during both exercise and rest. Work continued for 8 hours total time including donning the PC, or subject refusal to continue. Total work time (TWT) was total number of minutes worked. Rest time was the time sitting quietly in the same environment with the mask and gloves removed and the upper half of the protective coveralls pulled down to the waist.

\section{RESULTS}

Equations were derived as shown in Table I. The variance in work time accounted for by easily measured variables was much lower than was seen in pilot work in military PC (5).

\section{CONCLUSIONS}

In summary, it does not appear that our bench step field test of work tolerance in PC permits highly accurate predictions of performance. However, this approach could be broadly useful in determining which workers are most at risk, and which are most suited for work in warm environments in PC. Despite objections to screening workers for particular jobs, it would be reasonable from both the safety and productivity perspectives, to attempt to classify workers as tolerant to PC use in 
Table 1. Regression equations for best prediction of total work time for each work and environmental condition for all subjects $(n=50)$.

\begin{tabular}{|c|c|c|c|c|}
\hline Variable & $\begin{array}{c}\text { Beta } \\
\text { Weight }\end{array}$ & $\overline{\mathrm{R}^{2}(\mathrm{ADJ} .)}$ & $\begin{array}{l}\text { Syx } \\
(\min )\end{array}$ & $\begin{array}{l}\text { C.V. } \\
(\%)\end{array}$ \\
\hline \multicolumn{5}{|c|}{ WBGT $=18^{\circ} \mathrm{C} /$ Work rate $=1.0 \mathrm{~L} / \mathrm{min}$} \\
\hline Intercept & 179 & & & \\
\hline Bench 1 time & 2.7 & & & \\
\hline Bench 1 Comf rating & 16.6 & & & \\
\hline Bench 1 RPE & -8.4 & & & \\
\hline Bench 1 HR2 & -1.8 & (Heart rate at $2 \mathrm{~min}$ ) & & \\
\hline Bench 1 HR5 & 1.4 & (Heart rate at $5 \mathrm{~min}$ ) & & \\
\hline WT & 1.5 & $.26(.13)$ & 51 & 21 \\
\hline
\end{tabular}

WBGT $=18^{\circ} \mathrm{C} /$ Work rate $=1.3 \mathrm{~L} / \mathrm{min}$

$\begin{array}{lc}\text { Intercept } & 312 \\ \text { Bench 1 time } & 0.8 \\ \text { Bench 1 R.E } & 1.0 \\ \text { Bench 1 HR2 } & -0.9 \\ \text { HT } & 0.4 \\ \text { WT } & -2.9\end{array}$

WBGT $=26^{\circ} \mathrm{C} /$ Work rate $=1.0 \mathrm{~L} / \mathrm{min}$

Intercept 87

Bench 1 time $\quad 2.1$

Bench 1 Comf rating $\quad 12.5$

Bench 1 HR0

HT

-0.2 (Heart rate at $0 \mathrm{~min}$ )

$\begin{array}{llll}0.6 & .18(.09) & 37 & 36\end{array}$

WBGT $=26^{\circ} \mathrm{C} /$ Work rate $=1.3 \mathrm{~L} / \mathrm{min}$

Intercept

331

Bench 1 time

0.35

Bench 1 RPE

$-9.1$

Bench 1 HR0

$-1.7$

Bench 1 HR2

1.0

HT

AGE

$-3.8$

$.29(.18)$

43

35

ADJ. is the $\mathrm{R}^{2}$ adjusted for variable number and sample size (11), Syx is the standard error of prediction and C.V. is the coefficient of variation . 
heat or intolerant to this work. Such classifications might be very useful in safely increasing productivity.

\section{REFERENCES}

1. Bishop, P.A., Pieroni, R.E., Smith, J. and Constable, S.H. 1991, Limitation to heavy work at $21^{\circ} \mathrm{C}$ of personnel wearing the U.S. military chemical defense ensemble. Aviation Space and Environmental Medicine, 62(3): 216-220.

2. Bishop, P.A., Nunneley, S.A. and Constable, S.H. 1991, Comparisons of air and liquid personal cooling for intermittent heavy work in moderate temperatures. American Industrial Hygiene Association Journal, 52(9):393-397.

3. Bishop, P.A. 1990, A new approach to predicting response to work in thermally-challenging environments. Advances in Industrial Ergonomics and Safety II, 913-918.

4. Goldman, RF. 1985, Heat stress in industrial protective encapsulating garments. S.P. Levin and W.F. Martin, (eds), Protecting Personnel at Hazardous Waste Sites, Butterworth Boston.

5. Bishop, P.A., Smith, G., Ray, P., Beaird, J. and Smith, J. 1992, Empirical prediction of physiological response to prolonged work in encapsulating protective clothing. Ergonomics, 37(9): 1503-1512.

6. Kenny, WL, Lewis, DA, Anderson, RK, and Kamon, E. 1986, A simple test for the prediction of relative heat tolerance, American Industrial Hygiene Association Journal, 47(4) 203-206.

7. Shvartz, E, Shibolet, S, Meroz, A, Magazanik, and Shapiro, Y. 1977, Prediction of heat tolerance from heart rate and rectal temperature in a temperate environment, J. Appl. Physiol. Respir. Envir. and Exerc. Physiol., 43(4), 684-688.

8. Burton, A.C. 1935, Human Calorimetry II. The average temperature at the tissues of the body. J. Nutr. 9:261-280.

9. Vokac, A., V. Kopke, and Keul, P. 1976, Physiological responses and thermal, humidity, and comfort sensations in wear trials with cotton and polypropylene vest. Tex. Res. J. 46, 30-38.

10. Borg, G. 1972, Perceived exertion: A note on "history" and methods. Med. Sci. Sports, 5, 90-93.

11. Freund, RJ., Littell, R.C. and Spector, P.C. 1986, SAS System for Linear Models, SAS Institute Inc., Cary, NC, 15.

This study was funded in part by a grant from NOSH \# 1 ROI OH03015 01Al. 